\section{Integrating Host Resistance and Plant Protectants to Manage Pythium Root Rot on Geranium and Snapdragon}

\author{
Johanna Del Castillo Múnera ${ }^{1}$ and Mary K. Hausbeck ${ }^{2,3}$ \\ Department of Plant, Soil, and Microbial Sciences, Michigan State \\ University, East Lansing, MI 48824
}

Additional index words. Pythium ultimum, Pythium irregulare, Pythium aphanidermatum, cultural management practices

\begin{abstract}
Root rot caused by Pythium spp. is a significant disease on greenhouse-grown crops and negatively affects the floriculture industry. To develop strategies that limit Pythium root rot on geranium and snapdragon, greenhouse trials were conducted to test plant protectants and cultivars. Seven fungicides and two biological control agents were evaluated on plants inoculated with $P$. aphanidermatum, $P$. irregulare, or $P$. ultimum. Disease severity was assessed using a scale of 1 (healthy, no disease symptoms) to 5 (plant death) from 5 to 45 day postinoculation (dpi). The area under disease progress curve (AUDPC) values differed significantly $(P<0.0001)$ among Pythium spp. and treatment. The interaction between plant protectants and Pythium spp. was also significant. For geranium, mefenoxam (trade name: Subdue Maxx) and Streptomyces lydicus WYEC108 (trade name: Actinovate) effectively controlled Pythium root rot. For snapdragon, treatment efficacy varied depending on the Pythium sp. When 11 geranium cultivars were inoculated with $P$. aphanidermatum, none were completely resistant to the pathogen. However, when $P$. irregulare was used to inoculate these geranium cultivars, Nano White Hybrid and Bulls Eye Cherry were similar to the uninoculated control. When 12 snapdragon cultivars were inoculated with $P$. aphanidermatum or $P$. irregulare, no cultivar was completely resistant to either pathogen, but Twinny White and Candy Showers Yellow were least susceptible to both. Integrating effective fungicides with less susceptible cultivars can limit disease caused by Pythium spp.
\end{abstract}

Floriculture in the United States is an important agricultural enterprise (Daughtrey and Benson, 2005) with a wholesale value of $\$ 4.40$ billion (USDA, 2014). The ornamental industry is segmented among various types of growers who produce seeds, cuttings, prefinished, and/or finished plants (Daughtrey and Benson, 2005; Parke and Grünwald, 2012). Growers of floriculture crops must meet market demands for quality: limiting disease is important to optimize plant growth and flowering. Michigan leads the nation in sales for nine floriculture crops, including geranium, with an estimated wholesale value of \$375.74 million (USDA, 2013).

Pythium spp. infect greenhouse-grown crops and negatively affect the floriculture industry (Garzón et al., 2011). Pythium spp. can infect a wide variety of ornamental plants (Kucharek and Mitchell, 2000; Stephens and Powell, 1982). Disease symptoms caused by Pythium spp. include crown and root rot, seed

Received for publication 6 Apr. 2015. Accepted for publication 15 July 2015.

This research was supported by the Specific Cooperative Agreement 58-1907-0-096 with USDA-ARS under the Floriculture and Nursery Research Initiative and by the American Floral Endowment.

We thank B. Harlan for technical assistance and M. Quigley for assistance with statistical analyses. ${ }^{1}$ Graduate Research Assistant.

${ }^{2}$ Professor.

${ }^{3}$ Corresponding author. E-mail: hausbec1@msu. edu. and seedling damping-off, rot of the stem base, and stunting (Garzón et al., 2011; Martin and Loper, 1999). Root rot caused by Pythium spp. is a devastating disease if not detected and controlled adequately (Daughtrey and Benson, 2005; Garzón et al., 2011; Moorman and Kim, 2004). The incidence of Pythium spp. in floriculture crops was reported in Pennsylvania in 2002 (Moorman et al., 2002): $P$. irregulare and $P$. aphanidermatum were the most common species. In Michigan, it was found that $P$. irregulare, $P$. ultimum, and $P$. aphanidermatum were the species most frequently isolated from floriculture crops (Del Castillo-Múnera and Hausbeck, 2014).

Strategies commonly used to control Pythium root rot include using soilless media, disinfesting irrigation water in recirculating systems (Daughtrey and Benson, 2005), scouting crops, rogueing symptomatic plants, and applying fungicides and/or biological control agents (Moorman et al., 2002; Moorman and Kim, 2004). Currently, the number of plant protection products that are effective against Pythium spp. and registered for ornamentals is limited (Garzón et al., 2011). The fungicides mefenoxam, azoxystrobin, etridiazole, and fenamidone are used in greenhouse facilities to manage Pythium root rot (Cornell, 2012; Hausbeck and Harlan, 2013; Moorman and Kim, 2004). Mefenoxam, has been widely used to control Pythium spp. and Phytophthora spp. populations in greenhouse ornamentals (Daughtrey and Benson, 2005;
Hausbeck and Harlan, 2013; Moorman et al., 2002; Olson and Benson, 2011), and its repeated use has resulted in selection of resistant isolates of Pythium spp. (Garzón et al., 2011; Moorman and Kim, 2004; Taylor et al., 2002). Fungicides can be integrated with biological controls such as Trichoderma harzianum and S. lydicus that have been demonstrated to give Pythium root rot control (Daughtrey and Benson, 2005; Harman, 2000; Little et al., 2003; Moorman and Kim, 2004). Choosing cultivars based on pathogen resistance is not a common control strategy for floriculture producers (Garzón et al., 2011), and no recent reports are available to guide growers in selecting ornamental cultivars based on host resistance to Pythium root rot (Hausbeck et al., 1987). The objectives of this study were 1) to evaluate seven fungicides and two biological control agents for their ability to limit Pythium root rot in geranium and snapdragon, and 2) to evaluate geranium and snapdragon cultivars for their susceptibility to Pythium root rot.

\section{Materials and Methods}

Isolate selection and inoculum preparation. Isolates were selected from the collection of Pythium spp. previously isolated from various greenhouse floral crops in Michigan and maintained in the laboratory of M.K. Hausbeck at Michigan State University (MSU). Selected isolates were identified as $P$. irregulare sensu stricto (9.19A), P. ultimum (1.59A), and $P$. aphanidermatum (21.17B) by sequencing the internal transcribed spacer (ITS) region. The $P$. irregulare isolate (9.19A) was collected from geranium, and the P. ultimum (1.59A) and $P$. aphanidermatum (21.17B) isolates were obtained from poinsettia. $P$. ultimum and $P$. aphanidermatum isolates were sensitive to mefenoxam at $100 \mathrm{ppm}$, whereas the $P$. irregulare isolate was resistant to mefenoxam. Mefenoxam sensitivity was determined based on radial mycelial growth on corn meal agar (CMA) amended with 100 $\mathrm{ppm}$ of mefenoxam. An isolate was determined as resistant if radial mycelial growth was $>50 \%$ compared with the radial mycelial growth in unamended CMA (Del CastilloMúnera and Hausbeck, 2014; Olson and Benson, 2011).

Inoculum was produced by adding 18 plugs $(1.5 \mathrm{~cm}$ diameter) of actively growing mycelia in CMA culture to mushroom bags (RJG Sales and Supply, New Port Richey, FL) containing $600 \mathrm{~g}$ of millet seeds mixed with asparagine $(0.48 \mathrm{~g})$ and water $(432 \mathrm{~mL})$ that had been autoclaved twice (QuesadaOcampo et al., 2009). The inoculated millet seeds were incubated at $20^{\circ} \mathrm{C}$ under constant fluorescent light for 2 weeks and bags were shaken every other day to disperse the inoculum evenly.

Plant protection trial. The plant protection experiment was conducted during March (trial 1) and May (trial 2) 2014 at the MSU Plant Sciences Research Greenhouses. Geranium (Pelargonium $\times$ hortorum) 'Pinto 
Premium Red Deep', and snapdragon (Antirrhinum majus) 'Liberty Classic White' seeds (Ball Horticultural Company, West Chicago, IL) were sown in 128-cell plug trays filled with soilless media (Suremix; MI Grower Products Inc., Galesburg, MI) and maintained on a raised plant bench. Seedlings were overhead irrigated as needed and fertilized according to standard commercial practice.

A preliminary experiment was conducted to determine the amount of inoculum needed to cause plant death on $50 \%$ of untreated inoculated plants. It was found that $3 \mathrm{~g}$ of inoculum for $P$. irregulare and $P$. ultimum, and $2 \mathrm{~g}$ for $P$. aphanidermatum were needed to cause plant death in more than $50 \%$ of the plants inoculated.

For the trial, inoculum of each isolate was added to the top of $5.5 \times 7.0 \times 7.0 \mathrm{~cm}$ plastic pots containing soilless media, into which 8-week-old geranium 'Pinto Premium Red Deep' and snapdragon 'Liberty Classic White' seedlings were transplanted. Pots were placed on saucers and grown on a raised plant bench in the MSU Plant Sciences Research Greenhouses for $45 \mathrm{~d}$. The mean air temperature ranged from 19.4 to $27.22{ }^{\circ} \mathrm{C}$ during trial 1 and from 25.4 to $27.1{ }^{\circ} \mathrm{C}$ during trial 2. Plants were irrigated from the bottom as needed or about every second day. Biological control agents were applied as a drench $3 \mathrm{~d}$ before inoculation to transplanted plants; and fungicide treatments were applied as a soil drench the same day, which plants were inoculated at a volume of $70 \mathrm{~mL} /$ $35 \mathrm{~cm}^{2}$. Controls consisted of untreated uninoculated plants, and untreated inoculated plants. Treatments were chosen based on the mode of action, and applied according to labeled rates and reapplication intervals (Table 1). A completely randomized experimental design with six replicates was used. The design consisted of 2 plant species $\times 3$ Pythium spp. $\times 11$ plant protection treatments. The treatments included seven fungicides, two biological controls, and the untreated uninoculated and untreated inoculated controls. Each plant was considered an experimental unit. A single fungicide + pathogen isolate combination was assigned randomly to each plant.

Disease severity was assessed at 5-d intervals from 5 to 45 dpi. Plants were visually assessed using a 1 to 5 scale where $1=$ no symptoms; $2=$ lower leaves with chlorosis and slight wilting; $3=$ moderate chlorosis, wilting, and stem discoloration; $4=$ wilting and stunting; and $5=$ plant death. The AUDPC values were calculated using these disease severity ratings (Shaner and Finney, 1977). Plant height and width were also measured on the same day as disease severity.

Cultivars. All trials were conducted at the MSU Plant Sciences Research Greenhouses. Geranium cultivars were selected (Table 4) and trials conducted during May (trial 1) and July (trial 2) 2014. Snapdragon cultivars (Table 5) were obtained for trials that were conducted during June (trial 1) and Oct. (trial 2) 2014. Seeds were obtained from Ball
Table 1. Fungicides, rates and frequency of application for managing Pythium root rot caused by Pythium spp. on geranium and snapdragon in greenhouse trials.

\begin{tabular}{|c|c|c|c|c|c|}
\hline Trade name & Active ingredient & Manufacturer $^{2}$ & FRAC code & Rate/L & $\overline{\text { Frequency }(\mathrm{d})}$ \\
\hline Subdue maxx & Mefenoxam & Syngenta & 4 & $0.08 \mathrm{~mL}$ & 30 \\
\hline Terrazole & Etridiazole & OHP & 14 & $0.5 \mathrm{~mL}$ & 30 \\
\hline Heritage & $\begin{array}{l}\text { Azoxystrobin } \\
\text { Trichoderma }\end{array}$ & Syngenta & 11 & $0.07 \mathrm{~g}$ & 14 \\
\hline Rootshield & harzianum $\mathrm{T}-22$ & BioWorks & & $0.4 \mathrm{~g}$ & 14 \\
\hline Segway & Cyazofamid & $\begin{array}{l}\text { FMC } \\
\text { Phoenix } \\
\quad \text { Environmental }\end{array}$ & 21 & $0.3 \mathrm{~mL}$ & 14 \\
\hline Vital & Potassium phosphite & Care & 33 & $1.6 \mathrm{~mL}$ & 14 \\
\hline Adorn & Fluopicolide & Valent & 43 & $0.2 \mathrm{~mL}$ & 14 \\
\hline FenStop & $\begin{array}{l}\text { Fenamidone } \\
\text { Streptomyces lydicus }\end{array}$ & OHP & 11 & $1.1 \mathrm{~mL}$ & 30 \\
\hline Actinovate SP & WYEC108 & Natural Industries & & $0.45 \mathrm{~g}$ & 14 \\
\hline
\end{tabular}

${ }^{\mathrm{z}}$ Syngenta $=$ Syngenta Crop Protection Inc., Greensboro, NC; OHP = OHP Inc, Mainland, PA; BioWorks = BioWorks Inc., Victor, NY; FMC = FMC Corp., Agricultural Products Group, Philadelphia, PA; Phoenix Environmental Care $=$ Phoenix Environmental Care, LLC, Valdosta, GA; Valent $=$ Valent USA Corp., Walnut Creek, CA; Natural Industries = Natural Industries Inc., Houston, TX.

${ }^{\mathrm{y}} \mathrm{FRAC}=$ Fungicide Resistance Action Committee.

Table 2. Area under the disease progress curve (AUDPC) values for disease severity of geranium growing in greenhouse trials to evaluate plant protection products applied as a soil drench to control root rot caused by Pythium spp.

\begin{tabular}{lccc}
\hline & \multicolumn{3}{c}{ AUDPC for geranium inoculated with Pythium spp. $^{\mathrm{y}}$} \\
\cline { 2 - 4 } Treatment & P. aphanidermatum & P. irregulare & $P$. ultimum \\
\hline Untreated no inoculated & $40.0 \mathrm{aA}$ & $40.0 \mathrm{aA}$ & $40.0 \mathrm{aA}$ \\
Actinovate & $52.0 \mathrm{aA}$ & $54.5 \mathrm{aA}$ & $62.7 \mathrm{aAB}$ \\
Subdue Maxx & $66.7 \mathrm{aAB}$ & $91.5 \mathrm{bB}$ & $45.2 \mathrm{aA}$ \\
Rootshield & $67.6 \mathrm{abBC}$ & $102.0 \mathrm{~b}-\mathrm{dC}$ & $89.04 \mathrm{bcC}$ \\
Fenstop & $98.5 \mathrm{bcBC}$ & $94.9 \mathrm{bcBC}$ & $96.4 \mathrm{cC}$ \\
Heritage & $103.9 \mathrm{c}-\mathrm{eC}$ & $93.1 \mathrm{bBC}$ & $72.3 \mathrm{bBC}$ \\
Vital & $105.1 \mathrm{c}-\mathrm{eCD}$ & $100.1 \mathrm{~b}-\mathrm{dCD}$ & $83.9 \mathrm{bcC}$ \\
Terrazole & $107.5 \mathrm{c}-\mathrm{eC}$ & $94.1 \mathrm{bcBC}$ & $64.2 \mathrm{abB}$ \\
Adorn & $107.7 \mathrm{c}-\mathrm{eCD}$ & $108.2 \mathrm{cdCD}$ & $89.1 \mathrm{cC}$ \\
Segway & $128.6 \mathrm{deD}$ & $138.0 \mathrm{dD}$ & $66.4 \mathrm{bBC}$ \\
Untreated inoculated & $151.1 \mathrm{eE}$ & $126.3 \mathrm{dE}$ & $65.5 \mathrm{bC}$ \\
\hline
\end{tabular}

${ }^{2}$ Plant protection products were applied as a soil drench following inoculation with $P$. aphanidermatum, $P$. irregulare, or $P$. ultimum. Biological control agents were applied as soil drench three days before Pythium spp. inoculation.

${ }^{y} A U D P C$ values were calculated by using disease severity ratings at 5 -d intervals for $45 \mathrm{~d}$ postinoculation. AUDPC means within columns followed by the same lowercase letter are not significantly different with regard to product treatment, and means within rows followed by the same upper case letter are not significantly different with regard to the Pythium spp. inoculated (least square means significant difference at $P=0.05$ ).

Table 3. Area under the disease progress curve (AUDPC) values for disease severity of snapdragon growing in greenhouse trials to evaluate plant protection products applied as a soil drench to control root rot caused by Pythium spp.

\begin{tabular}{lccc}
\hline & \multicolumn{2}{c}{ AUDPC for snapdragon inoculated with Pythium spp. $^{\mathrm{y}}$} \\
\cline { 2 - 4 } Treatment & P. ${ }^{\mathrm{z}}$ aphanidermatum & $P$. irregulare & $P$. ultimum $^{-}$ \\
\hline Untreated no inoculated & $40.0 \mathrm{aA}$ & $40.0 \mathrm{aA}$ & $40.0 \mathrm{aA}$ \\
Fenstop & $83.17 \mathrm{abB}$ & $110.7 \mathrm{bBC}$ & $62.5 \mathrm{a}-\mathrm{cB}$ \\
Subdue Maxx & $85.36 \mathrm{bB}$ & $126.4 \mathrm{bcBC}$ & $42.3 \mathrm{aA}$ \\
Terrazole & $92.24 \mathrm{bcC}$ & $167.7 \mathrm{cdD}$ & $51.9 \mathrm{abB}$ \\
Rootshield & $94.67 \mathrm{bcBC}$ & $67.9 \mathrm{abB}$ & $89.9 \mathrm{cBC}$ \\
Adorn & $99.12 \mathrm{cdBC}$ & $156.1 \mathrm{cdD}$ & $42.7 \mathrm{aA}$ \\
Vital & $121.37 \mathrm{dD}$ & $95.1 \mathrm{bC}$ & $109.5 \mathrm{cCD}$ \\
Segway & $121.82 \mathrm{dD}$ & $135.7 \mathrm{cD}$ & $90.5 \mathrm{cD}$ \\
Actinovate & $124.91 \mathrm{dD}$ & $156.9 \mathrm{cdDE}$ & $82.6 \mathrm{cBC}$ \\
Heritage & $145.02 \mathrm{dD}$ & $138.9 \mathrm{cD}$ & $86.9 \mathrm{cB}$ \\
Untreated inoculated & $98.32 \mathrm{cdD}$ & $147.9 \mathrm{cdDE}$ & $90.5 \mathrm{cD}$ \\
\hline
\end{tabular}

${ }^{2}$ lant protection products were applied as a soil drench following inoculation with $P$. aphanidermatum, $P$. irregulare, or P. ultimum. Biological control agents were applied as soil drench $3 \mathrm{~d}$ before Pythium spp. inoculation.

${ }^{y}$ AUDPC values were calculated by using disease severity ratings at 5 -d intervals for $45 \mathrm{~d}$ postinoculation. AUDPC means within columns followed by the same lowercase letter are not significantly different with regard to product treatment, and means within rows followed by the same upper case letter are not significantly different with regard to the Pythium spp. inoculated (least square means significant difference at $P=0.05$ ). 
Horticultural Company, with the exception of the geranium cultivars Inspire Appleblossom Hybrid and Nano White Hybrid, which were obtained from Park Seed Co. (Greenwood, SC). Seeds were sown into plug trays as previously described and grown for 8 weeks. Seedlings were overhead irrigated as needed and fertilized twice weekly with 200 ppm Peter's 20-20-20 liquid fertilizer (The Scotts Company, Marysville, $\mathrm{OH}$ ). Plants were then transplanted into pots containing media infested with $P$. irregulare (9.19A) or $P$. aphanidermatum (21.17B) using methods similar to that described for the fungicide trials. The daily mean air temperature during the geranium cultivar trial ranged from 25.30 to $32.33^{\circ} \mathrm{C}$ (trial 1 ), and from 27.77 to $33.77^{\circ} \mathrm{C}$ (trial 2). The mean air temperature during the snapdragon cultivar trial ranged from 31.80 to $33.10{ }^{\circ} \mathrm{C}$ (trial 1) and from 26.40 to $30.40{ }^{\circ} \mathrm{C}$ (trial 2). A completely randomized experimental design with eight replicates per cultivar was used. A single pathogen isolate was assigned randomly to each plant. Disease severity was assessed at 5-d intervals from 5 to $35 \mathrm{dpi}$. Plants were visually assessed using the disease scale specified above.

Pathogen confirmation. On experiment completion, $\approx 15 \%$ of symptomatic inoculated plants were randomly selected for pathogen confirmation. Four pieces $(0.8$ $\mathrm{cm}$ length) of symptomatic plant roots were washed under running tap water, cut, airdried, and placed onto CMA amended with ampicillin $\left(0.25 \mathrm{mg} \cdot \mathrm{L}^{-1}\right)$, rifampicin $\left(0.01 \mathrm{~g} \cdot \mathrm{L}^{-1}\right)$, pentachloronitrobenzene $\left(0.1 \mathrm{~g} \cdot \mathrm{L}^{-1}\right)$, and benomyl $\left(0.05 \mathrm{~g} \cdot \mathrm{L}^{-1}\right)$. Isolates resembling Pythium spp. were initially confirmed via microscopic observation of oogonia and sporangia following the van der Plaats-Niterink identification key (van der Plaats-Niterink, 1981), and mycelial growth was transferred and purified in amended CMA.

The isolates were identified by sequencing the ITS region following the procedure similar to Weiland (2011). In brief, a colony polymerase chain reaction (PCR) was performed for each Pythium spp. culture. A small quantity of hyphae was taken from each culture with a sterile toothpick, transferred to a $500-\mu \mathrm{L}$ microfuge tube containing $100 \mu \mathrm{L}$ of double-distilled sterile water and incubated at $95^{\circ} \mathrm{C}$ for $5 \mathrm{~min}$ (Weiland, 2011). Two microliters of the extract were added to a $25 \mu \mathrm{L}$ PCR reaction that consisted of $2 \mathrm{~mm}$ $\mathrm{MgCl}_{2}, 1 \times$ buffer, $0.2 \mu \mathrm{M}$ deoxynucleotide triphosphates, $0.2 \mu \mathrm{M}$ of primers ITS5 and ITS4 (White et al., 1990), and 1U of Taq polymerase. Amplifications were performed on a Mastercycler thermal cycler (Eppendorf North America, Hauppauge, NY) with initial denaturation at $96^{\circ} \mathrm{C}$ for $3 \mathrm{~min}$, followed by 35 cycles of $96^{\circ} \mathrm{C}$ for $1 \mathrm{~min}, 55^{\circ} \mathrm{C}$ for $1 \mathrm{~min}$, $72{ }^{\circ} \mathrm{C}$ for $2 \mathrm{~min}$, and a final extension at $72^{\circ} \mathrm{C}$ for $10 \mathrm{~min}$. Samples were visualized by $1 \%$ agarose gel electrophoresis using Quantity One Software (Bio-Rad, Hercules, CA), and sequenced at Macrogen (Rockville, MD). Resulting sequences were compared with a local library, built with curated sequences from Robideau et al. (2011), using CLC Main Workbench (CLCbio, Aarhus, Denmark).

Statistical analyses. The AUDPC values and the days to symptom development data were analyzed by analysis of variance (ANOVA) using the Proc Mixed procedure of SAS 9.3 (SAS Institute Inc., Cary, NC). For the fungicide experiment, the trials were considered random variables. Treatments, plant species, and Pythium spp. were considered fixed variables. For the cultivar experiment, trials were also considered random variables. Cultivars and Pythium spp. were considered fixed variables. For the cultivar experiment, there were no significant differ- ences among the trials for each crop, so data were pooled and analyzed together. If variances were unequal, the group option of the repeated statement was used with degrees of freedom according to Kenward-Roger. If ANOVA was significant for main effects or interaction terms, treatment means were compared using $t$ test (least square means test at $P=0.05$ ) and adjusted with Dunnett. To test simple main effects, the slice statement was used when the interactions were significant.

Disease severity data were analyzed with the Proc Glimmix procedure of SAS 9.3 using a multinomial distribution, and comparisons were made using contrasts.
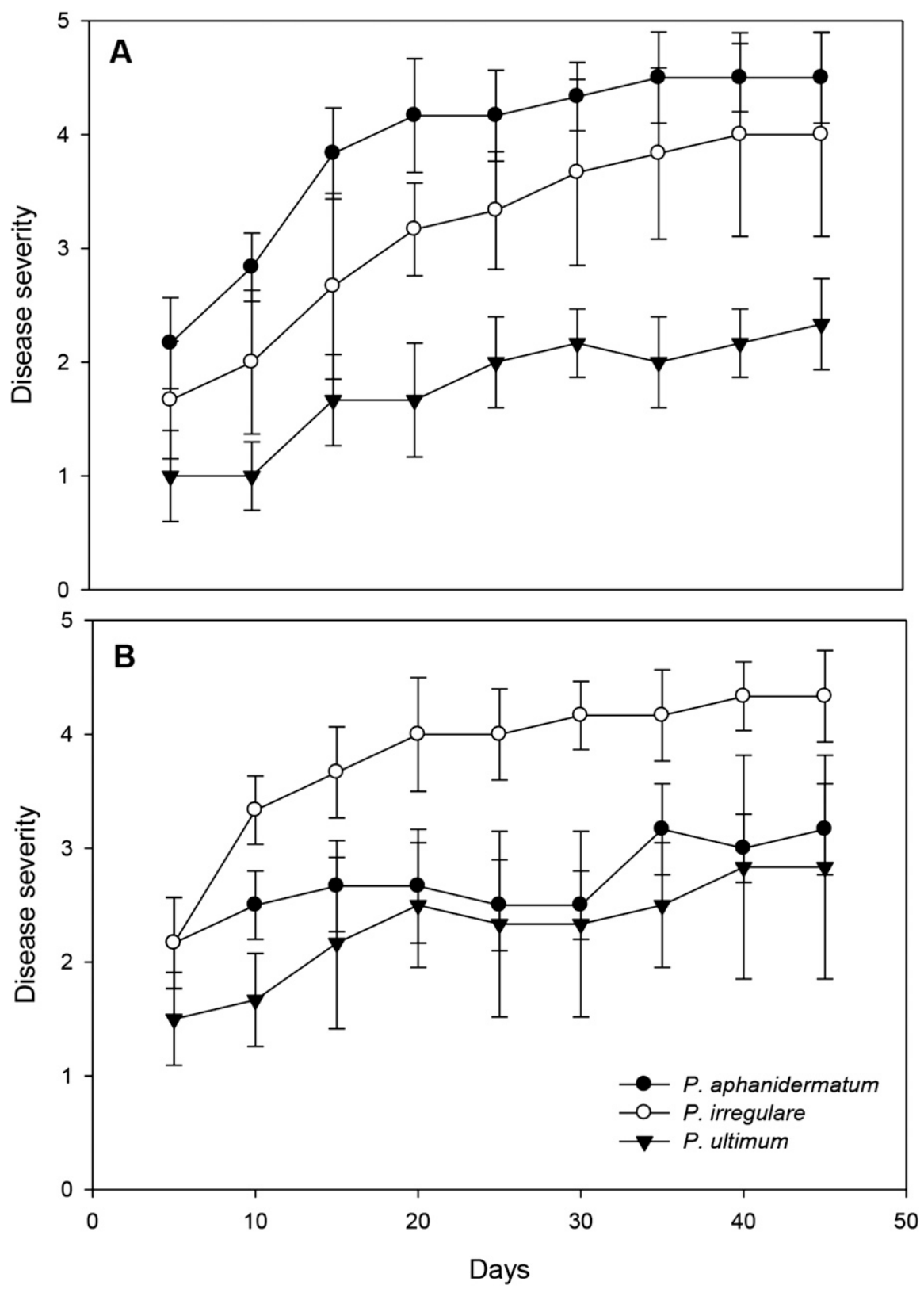

Fig. 1. Development of Pythium root rot on (A) geranium and (B), snapdragon inoculated with $P$. aphanidermatum, $P$. irregulare, and $P$. ultimum in greenhouse trials evaluating the efficacy of products. Root rot was rated from 5 to $45 \mathrm{~d}$ postinoculation on a 1 to 5 scale, where $1=$ no symptoms, $2=$ lower leaves with chlorosis and slightly wilted, $3=$ moderate chlorosis, wilting and stem discoloration, 4 = wilting and stunting of the entire plant, $5=$ plant death. Ratings are the means of the untreated inoculated plants. Error bars represent the standard error of the mean. 


\section{Results}

Plant protection. The Pythium spp. used in this experiment caused typical aboveground root rot symptoms such as wilting and stunting in geranium and snapdragon seedlings. Untreated uninoculated plants did not exhibit disease symptoms. Disease severity and incidence in trial 2 was higher than that in trial 1. The mean AUDPC for the untreated inoculated geranium was 75.9 and 114.3 for trial 1 and trial 2, respectively. For the untreated inoculated snapdragon, the AUDPC in trial 1 was 105.4 and 112.2 for trial 2. There were significant differences between the two trials, but the results revealed a similar trend of effectiveness among the plant protectants. Data are pre-

Table 4. Area under the disease progress curve (AUDPC) values for disease severity of geranium cultivars growing in greenhouse trials evaluating host resistance to root rot caused by Pythium aphanidermatum and Pythium irregulare.

\begin{tabular}{lcc}
\hline & \multicolumn{2}{c}{ AUDPC $^{\mathrm{z}}$} \\
\cline { 2 - 3 } Geranium cultivar & $P$. aphanidermatum & P. irregulare \\
\hline Ivy Summer Showers Fuchsia & $75.1 \mathrm{a}^{*}$ & $46.5 \mathrm{ab}^{*}$ \\
Ivy Tornado Red & $75.1 \mathrm{a}^{*}$ & $47.1 \mathrm{ab}^{*}$ \\
Inspire Appleblossom Hybrid & $88.9 \mathrm{ab}^{*}$ & $61.8 \mathrm{~b}^{*}$ \\
Nano White Hybrid & $91.7 \mathrm{ab}^{*}$ & $35.5 \mathrm{a}^{\mathrm{NS}}$ \\
Horizon Red & $102.5 \mathrm{~b}^{*}$ & $37.6 \mathrm{a}^{\mathrm{NS}}$ \\
Ringo 2000 Red Deep & $105.3 \mathrm{~b}^{*}$ & $41.4 \mathrm{a}^{*}$ \\
Maverick Red & $107.1 \mathrm{~b}^{*}$ & $43.4 \mathrm{ab}^{*}$ \\
Score Cherry Picotee & $107.4 \mathrm{~b}^{*}$ & $43.8 \mathrm{ab}^{*}$ \\
Bullseye Cherry & $108.1 \mathrm{~b}^{*}$ & $35.8 \mathrm{ab}^{\mathrm{NS}}$ \\
Multibloom Salmon & $114.8 \mathrm{~b}^{*}$ & $52.2 \mathrm{ab}^{*}$ \\
Pinto Premium Red Deep & $116.7 \mathrm{~b}^{*}$ & $52.4 \mathrm{ab}^{*}$ \\
\hline
\end{tabular}

${ }^{\mathrm{z}}$ AUDPC values were calculated by using disease severity ratings at 5-d intervals for 35 d postinoculation. AUDPC means within columns followed by the same lowercase letter are not significantly different. Values followed by an asterisk are significantly different from their control; values followed by ns are not significantly different from their control (least square means significant difference at $P=0.05$ ).
WYEC108 limited disease on geranium inoculated with each one of the three Pythium spp.; AUDPC values were significantly different from those of the untreated inoculated plants (Table 2). The treatments with etriadiazole and potassium phosphite only gave barely significant benefit for geranium inoculated with $P$. irregulare, and no benefit for geranium inoculated with $P$. aphanidermatum or P. ultimum. Cyazofamid and fluopicolide did not limit disease significantly compared with the untreated inoculated control.

For snapdragons, product efficacy depended on the Pythium sp. Mefenoxam and fenamidone significantly reduced disease caused by $P$. aphanidermatum and $P$. ultimum compared with the untreated inoculated control. Also, the treatments with fluopicolide and etridiazole reduced the symptoms caused by $P$. ultimum. Trichoderma harzianum T-22, potassium phosphite, and fenamidone effectively controlled $P$. irregulare (Table 3 ). Neither cyazofamid nor $S$. lydicus WYEC108 reduced disease by any of the Pythium spp. on snapdragon. Plant height and volume for geranium and snapdragon did not differ significantly among plant protectants and Pythium spp.

Geranium cultivars. Pythium aphanidermatum and $P$. irregulare caused disease in all geranium cultivars tested. No cultivar was resistant. Plant death at $35 \mathrm{dpi}$ was greater than $60 \%$ or $30 \%$ for the most susceptible cultivars inoculated with $P$. aphanidermatum, and $P$. irregulare, respectively. There were not significant differences between the two trials, so data were pooled and analyzed together. The AUDPC values were

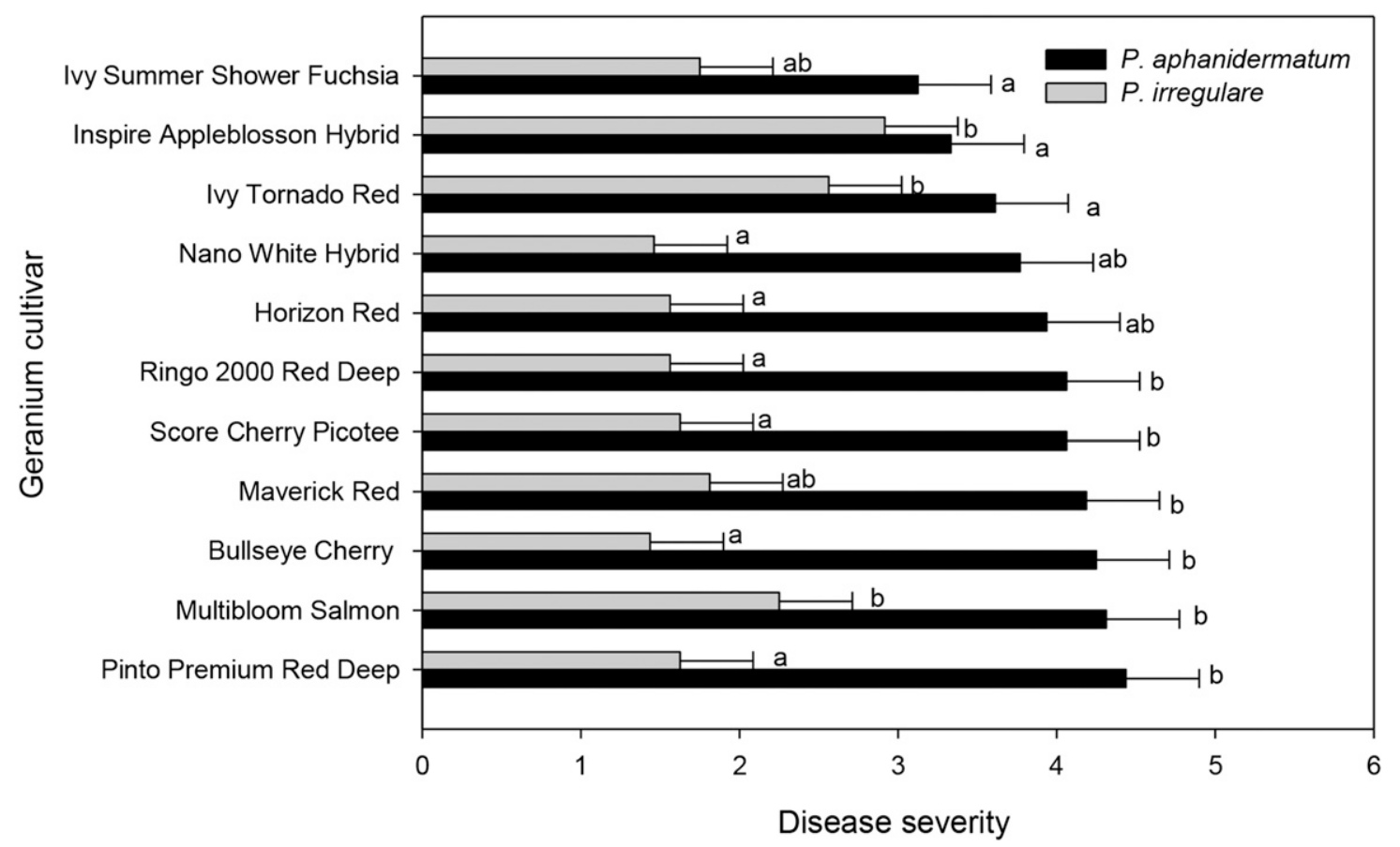

Fig. 2. Disease severity $35 \mathrm{~d}$ postinoculation in geranium cultivars growing in the greenhouse evaluated for susceptibility to root rot caused by $P$. aphanidermatum and $P$. irregulare. Values represent the means of eight replicates. No disease developed in the uninoculated controls. Error bars represent the standard error of the mean. Bars with a letter in common are not significantly different within each cultivar based on least square means significant difference at $P<0.05$. 
significant for geranium cultivar $(P=$ $0.0007)$, Pythium spp. $(P<0.0001)$, and the interaction between them $(P=0.0032)$. In general, $P$. aphanidermatum caused higher disease severity than $P$. irregulare in the geranium cultivars tested (Fig. 2). No cultivar was resistant to $P$. aphanidermatum, but Ivy Summer Shower Fuchsia, Ivy Tornado Red, and Inspire Appleblosson Hybrid had the lowest AUDPC values (Table 4), and the lowest disease severity at the last rating date (Fig. 2). The AUDPC values of 'Nano White Hybrid', 'Bulls Eye Cherry', and 'Horizon Red' inoculated with $P$. irregulare did not significantly differ from the uninoculated control. The average disease severity measured in the last rating date was below 2.0 for these cultivars (Fig. 2).

Symptom appearance varied significantly within cultivar $(P=0.0016)$ for each $P$ ythium sp. $(P<0.0001)$. In general, geranium cultivars inoculated with $P$. aphanidermatum exhibited disease symptoms sooner than cultivars inoculated with $P$. irregulare (Fig. 3). 'Ivy Summer Shower Fuchsia' and 'Ivy Tornado Red' inoculated with $P$. aphanidermatum developed disease symptoms significantly later $(\approx 17 \mathrm{dpi})$ than other cultivars tested (Fig. 3). The cultivars Nano White Hybrid, Bullseye Cherry, and Ivy Summer Shower Fuchsia inoculated with $P$. irregulare developed disease symptoms significantly slower $(\approx 30 \mathrm{dpi})$. The susceptible cultivars Inspire Appleblossom Hybrid, Pinto Premium Red Deep, and Multibloom Salmon inoculated with either of the Pythium spp. exhibited disease symptoms faster.

Snapdragon cultivars. Pythium aphanidermatum and $P$. irregulare caused disease in the snapdragon cultivars tested. No cultivar was disease resistant. Plant death at 35 dpi was greater than $60 \%$ for the most susceptible cultivars inoculated with $P$. aphanidermatum or $P$. irregulare. There were not significant differences between the two trials, so data were pooled and analyzed together. The AUDPC values were significant for snapdragon cultivars and Pythium spp. $(P<$ 0.0001). 'Twinny White', 'Candy Showers Yellow', 'Montego White', and 'Arrow White' were least susceptible (Table 5; Fig. 4). The AUDPC value for these cultivars inoculated with $P$. irregulare was not significantly different from the uninoculated control. The cultivar most susceptible to both pathogens was 'Bells White'.

Symptom appearance among cultivars did not vary significantly $(P=0.2362)$. However, differences among the Pythium spp. $(P=$ $0.017)$ and the interaction between cultivar and Pythium spp. $(P=0.05)$ were significant. 'Sonnet White', 'Snapshot White', and 'Arrow White' inoculated with $P$. aphanidermatum developed symptoms significantly later than the other cultivars tested $(\approx 15 \mathrm{dpi})$. 'Twinny White' and 'Liberty Classic White' were inoculated with $P$. irregulare and exhibited disease symptoms at $\approx 29 \mathrm{dpi}$ (Fig. 5). The most susceptible cultivar Bells White, inoculated with both Pythium spp. exhibited disease symptoms at $7 \mathrm{dpi}$.

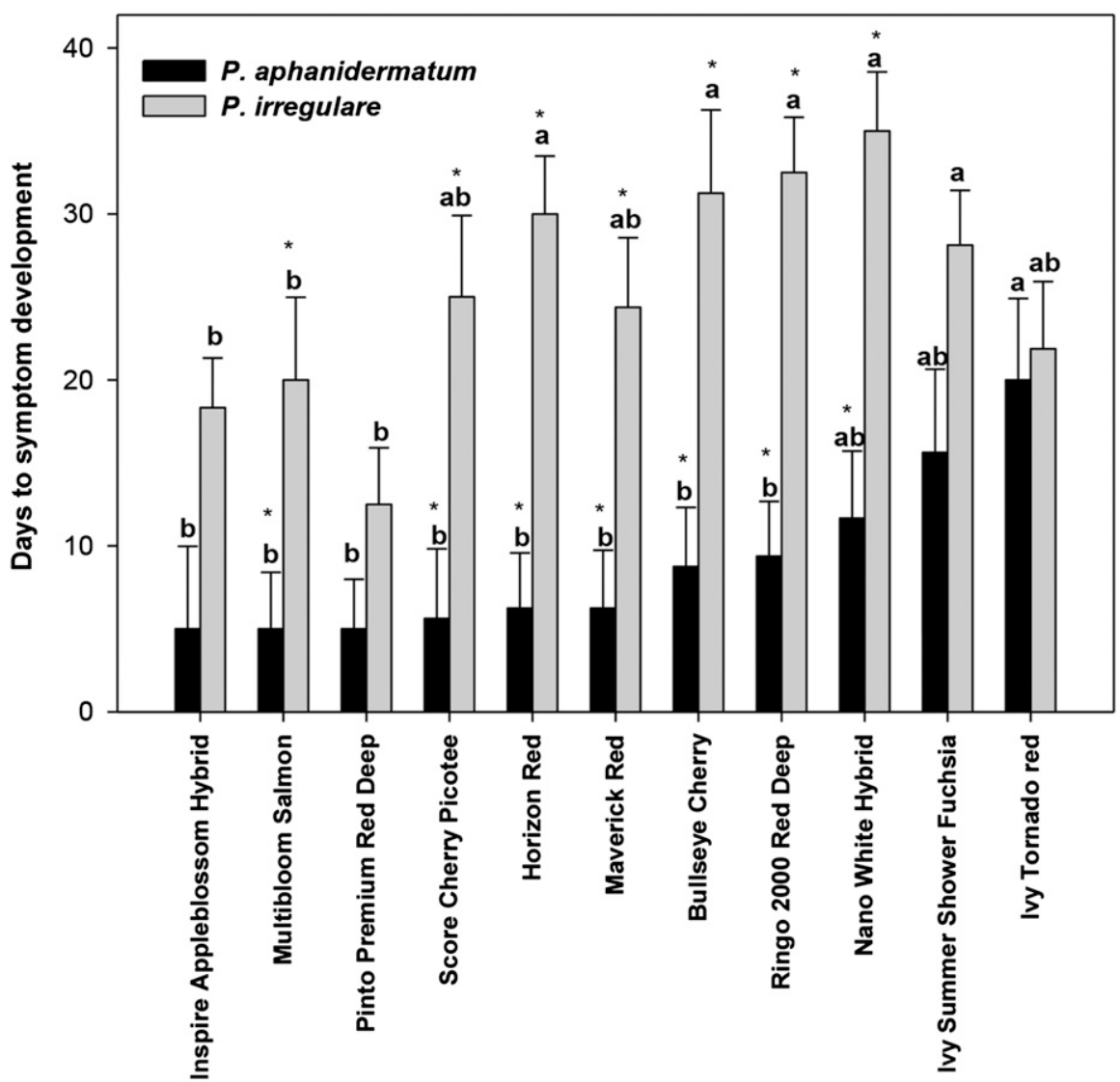

Geranium Cultivar

Fig. 3. Symptom appearance days postinoculation of geranium cultivars evaluating for susceptibility to root rot caused by $P$. aphanidermatum (21.17B) and $P$. irregulare (9.19A). Values represent the means of eight replicates. No disease developed in the uninoculated controls. Error bars represent the standard error of the mean. Bars with a letter in common are not significantly different within each cultivar, and bars with asterisk are significantly different among isolates of Pythium spp. Analyses based on least square means significant difference at $P<0.05$.

Table 5. Area under the disease progress curve (AUDPC) values for disease severity of snapdragon cultivars growing in greenhouse trials evaluating host resistance to Pythium root rot caused by Pythium aphanidermatum and Pythium irregulare.

\begin{tabular}{lcr}
\hline & & AUDPC \\
\cline { 2 - 3 } Snapdragon cultivar & P. aphanidermatum & P. irregulare \\
\hline Twinny White & $77.9 \mathrm{a}^{*}$ & $48.9 \mathrm{a}^{\mathrm{Ns}}$ \\
Candy Shower Yellow & $81.6 \mathrm{a}^{*}$ & $61.5 \mathrm{a}^{\mathrm{Ns}}$ \\
Montego White & $83.3 \mathrm{a}^{*}$ & $66.3 \mathrm{ab}^{*}$ \\
Arrow White & $84.3 \mathrm{a}^{*}$ & $59.1 \mathrm{a}^{\text {Ns }}$ \\
Oh Snap White & $105.1 \mathrm{ab}^{*}$ & $71.7 \mathrm{ab}^{*}$ \\
Floral Shower White & $105.4 \mathrm{ab}^{*}$ & $77.5 \mathrm{ab}^{*}$ \\
Snapshot White & $109.6 \mathrm{ab}^{*}$ & $80.3 \mathrm{ab}^{*}$ \\
Sonnet White & $118.9 \mathrm{bc}^{*}$ & $113.2 \mathrm{bc}^{*}$ \\
Chimes Purple White & $123.9 \mathrm{bc}^{*}$ & $75.2 \mathrm{ab}^{*}$ \\
Solstice White & $124.9 \mathrm{bc}^{*}$ & $94.2 \mathrm{ab}^{*}$ \\
Liberty Classic White & $131.2 \mathrm{bc}^{*}$ & $64.0 \mathrm{a}^{*}$ \\
Bells White & $170.4 \mathrm{bc}^{*}$ & $139.8 \mathrm{c}^{*}$ \\
\hline TUUD
\end{tabular}

${ }^{2}$ AUDPC values were calculated by using disease severity ratings at 5 -d intervals for $35 \mathrm{~d}$ postinoculation. AUDPC means within columns followed by the same lowercase letter are not significantly different. Values followed by an asterisk are significantly different from their controls; values followed by ns are not significantly different from their control (least square means significant difference at $P=0.05$ ).

Pathogen confirmation. The Pythium spp. used for inoculum for the fungicide and cultivar experiments, were successfully reisolated from the infected root tissue of $15 \%$ of symptomatic plants in each experiment. Cultures isolated from symptomatic plants were identified by sequencing the ITS region. The identity of the pathogen collected from the plants was confirmed by obtaining identity greater than $98 \%$ to ITS sequences of $P$. aphanidermatum, $P$. irregulare, and $P$. ultimum, deposited in the curated database of Robideau et al. (2011). Control plants did not exhibit disease symptoms and Pythium spp. were not recovered from any of the untreated uninoculated controls. 


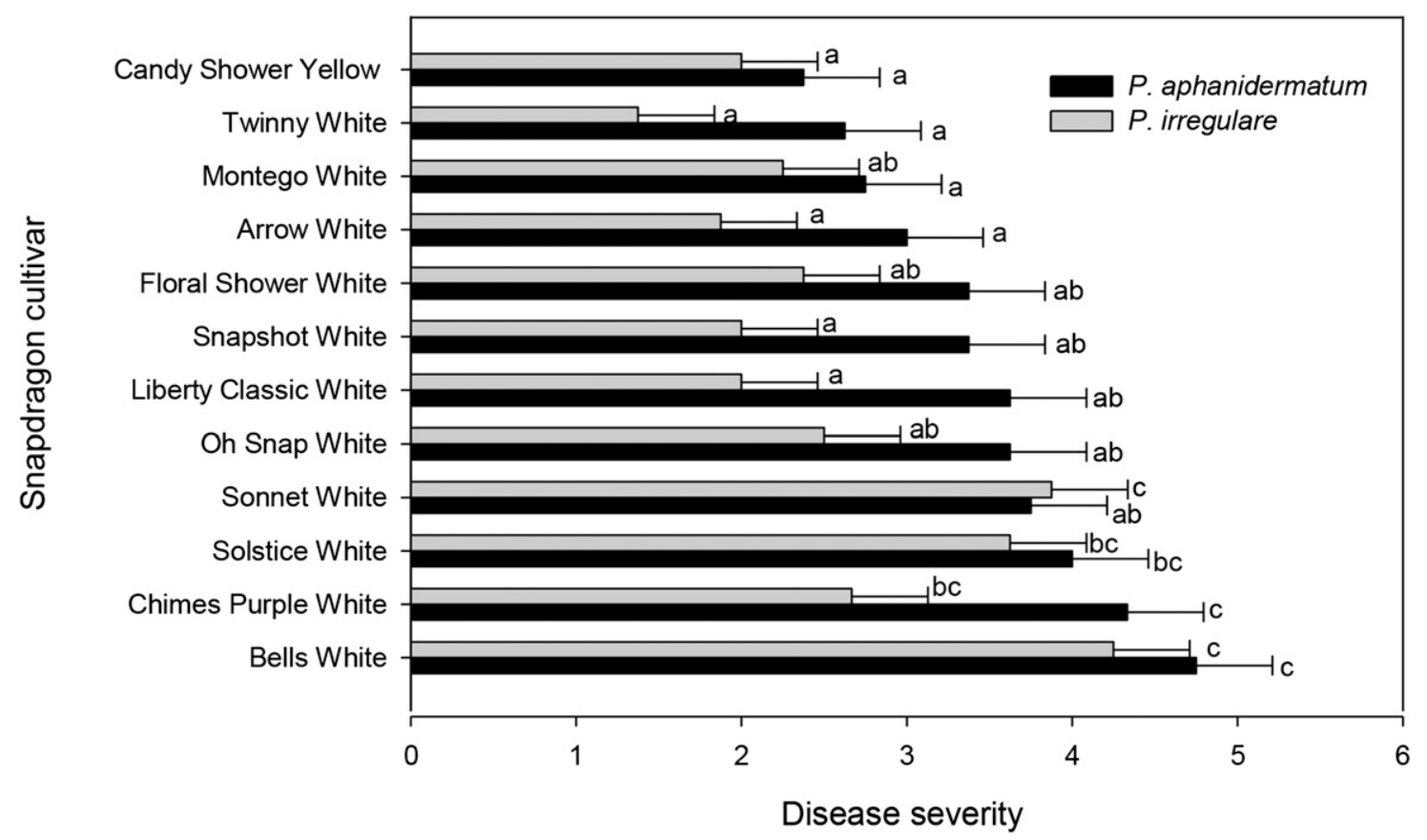

Fig. 4. Disease severity 35 d postinoculation in snapdragon cultivars in greenhouse evaluations for susceptibility to root rot caused by $P$. aphanidermatum and $P$. irregulare. Values represent the means of eight replicates. No disease developed in the uninoculated controls. Error bars represent the standard error of the mean. Bars with a letter in common are not significantly different within each cultivar based on least square means significant difference at $P<0.05$.

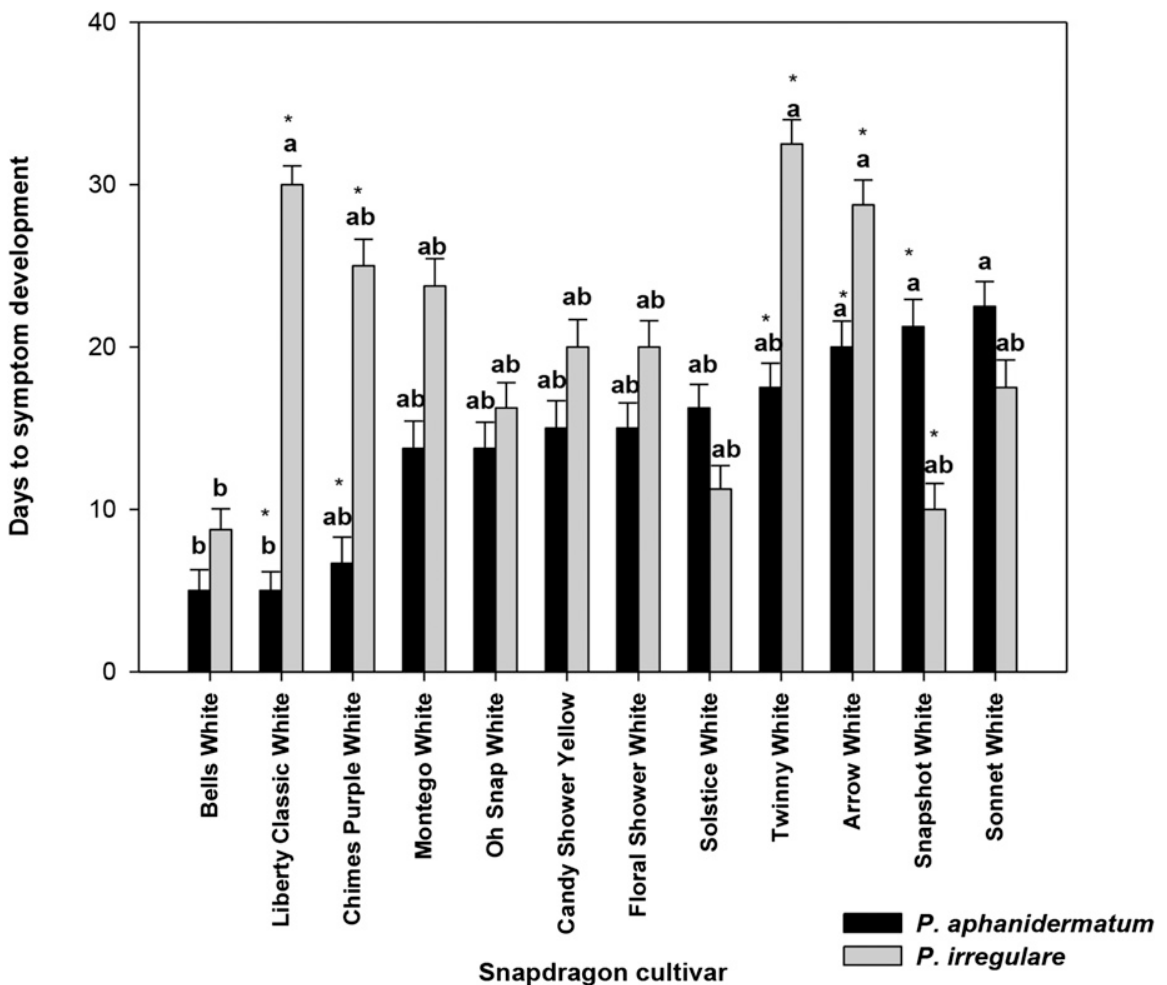

Fig. 5. Symptom appearance days postinoculation of snapdragon cultivars evaluating for susceptibility to root rot caused by P. aphanidermatum (21.17B) and P. irregulare (9.19A). Values represent the means of eight replicates. No disease developed in the uninoculated controls. Error bars represent the standard error of the mean. Bars with a letter in common are not significantly different within each cultivar, and bars with asterisk are significantly different among isolates of Pythium spp. Analyses based on least square means significant difference at $P<0.05$.

\section{Discussion}

Plant protectants and host resistance were evaluated as a means to manage highly virulent Pythium spp. commonly associated with floriculture crops in Michigan (Del Castillo-Múnera and Hausbeck, 2014). There are relatively few effective products regis- tered to control Pythium root rot in floriculture crops (Garzón et al., 2011). Options include the fungicides mefenoxam, etridiazole, azoxystrobin, and fenamidone (Cornell, 2012; Hausbeck and Harlan, 2013; Moorman and Kim, 2004). However, repeated use of mefenoxam has resulted in resistant Pythium spp. populations (Garzón et al., 2011; Moorman and Kim, 2004; Taylor et al., 2002) with resistant isolates reported in ornamentals (Moorman et al., 2002), potato (Taylor et al., 2002) and carrot (Lu et al., 2012).

In our study, plants inoculated with $P$. aphanidermatum were more severely diseased than plants inoculated with $P$. irregulare or P. ultimum. Mefenoxam and S. lydicus WYEC108 were most effective in limiting disease symptoms caused by $P$. aphanidermatum, $P$. irregulare, and $P$. ultimum on geranium, and $P$. aphanidermatum and $P$. ultimum on snapdragon. Mefenoxam has been widely used to control Pythium sp. in ornamentals, and effectively limits Pythium root rot in susceptible populations (Chase, 1993; Cohen and Coffey, 1986; Daughtrey and Benson, 2005; Hausbeck and Harlan, 2013; Moorman et al., 2002; Olson and Benson, 2011). Fungicide efficacy studies conducted with bermudagrass infected with $P$. aphanidermatum observed similarly to our results, that mefenoxam was highly effective when applied preventively and curatively (Stiles et al., 2005). Mefenoxam was also effective in preventing postemergence damping-off of Douglas fir seedlings infected with $P$. irregulare (Linderman et al., 2008). The isolate of $P$. irregulare used in this study was previously determined to be resistant to mefenoxam. However, mefenoxam limited $P$. irregulare in geranium, but not snapdragon 
(Table 2) surprisingly. Although the $P$. irregulare inoculum used in this study was obtained from single cultures derived from a hyphal tip; a possible contamination source in the greenhouse with a mefenoxam sensitive $P$. irregulare isolate may explain this unexpected result. Also, the disease severity of $P$. irregulare was higher on the untreated inoculated plants of snapdragon than geranium (Table 2). This higher disease severity and incidence of $P$. irregulare isolate on snapdragon, and its resistance to mefenoxam may explain the reduced effectiveness of this product compared with the results obtained from geranium. The inability of mefenoxam to limit root rot in tobacco seedlings has been reported in resistant isolates of $P$. myriotylum (Gutiérrez et al., 2012).

The biological control agent $S$. lydicus WYEC108 was one of the most effective treatments in limiting disease symptoms caused by $P$. aphanidermatum, $P$. irregulare, and $P$. ultimum on geranium, and $P$. ultimum on snapdragon. Streptomyces lydicus was first characterized by Yuan and Crawford (1995) as a potential antagonist of fungal root pathogens. Streptomyces spp. produce a wide range of antibiotics and fungal cell wall degrading enzymes including cellulases, hemicellulases, chitinases, and amylases, and are able to colonize the rhizosphere (Yuan and Crawford, 1995). Studies on poinsettia inoculated with $P$. ultimum showed that $S$. lydicus effectively controlled root rot. Inoculated poinsettias treated with $S$. lydicus exhibited a dry weight and number of shoots similar to those treated with mefenoxam and the control uninoculated plants (Little et al., 2003). The potential of $S$. lydicus to limit Pythium sp. was also determined in an in vitro assay that evaluated growth inhibition of several Pythium spp. isolates from Oregon nurseries (Weiland, 2014).

Streptomyces lydicus WYEC108 was more effective against Pythium spp. on geranium than snapdragon. It has been shown that the efficacy of biological control agents in controlling soilborne diseases can be variable (Handelsman and Stabb, 1996; Leisso et al., 2009; Linderman et al., 2008; Weiland, 2014; Whipps and McQuilken, 2009). Inconsistent results may be related to biotic and abiotic factors that affect the antagonistic properties of the biocontrol agents. These factors may include the influence of the microbiome inhabiting the rhizosphere of the plants, genotypic variability of the host plant and the pathogen, and environmental conditions including temperature, relative humidity, and ultraviolet radiation (Paulitz and Bélanger, 2001; Guetsky et al., 2002; Weiland, 2014). Differences in the efficacy of the biological control agents evaluated in this study may depend on the Pythium spp. Although $S$. lydicus WYEC108 effectively limited disease caused by $P$. aphanidermatum, $P$. irregulare, and $P$. ultimum in geranium, it did not effectively control $P$. irregulare in snapdragon

Although azoxystrobin was not among the most effective products in this study, disease severity was significantly reduced in azoxystrobin-treated geranium inoculated with $P$. irregulare, compared with the untreated inoculated control (Table 2). Gutiérrez et al. (2012) showed that azoxystrobin effectively controlled root rot in tobacco seedlings infected with a $P$. irregulare mefenoxamresistant isolate.

Snapdragon plants infected with $P$. aphanidermatum or $P$. ultimum had a relatively low disease severity when treated with fenamidone. To the authors' knowledge, the effectiveness of fenamidone against crown and root rot in ornamentals, has been reported for disease incited by the oomycete Phytophthora cryptogea (Benson and Parker, 2011), but not for Pythium spp. Benson and Parker (2011) showed that fenamidone reduced root rot on gerbera daisy inoculated with $P$. cryptogea in three trials, yet with no significant difference from the untreated uninoculated control. In our study, T. harzianum was the most effective treatment in limiting disease on snapdragon inoculated with $P$. irregulare. Trichoderma harzianum has been shown to effectively control root rot caused by $P$. ultimum on geranium (Harman, 2000) and poinsettia (Little et al., 2003) when applied preventively (Harman, 2000).

Disease pressure caused by the three Pythium spp. inoculated was significantly higher for trial 2 than trial 1: this could be a result of differences in temperatures. The mean air temperature was lower in trial 1 $\left(19.4\right.$ to $\left.27.22^{\circ} \mathrm{C}\right)$ compared with trial $2(25.4$ to $27.1{ }^{\circ} \mathrm{C}$ ). Ideal temperatures differ among Pythium spp. and their hosts (Martin and Loper, 1999). $P$. aphanidermatum and $P$. myriotylum caused high disease severity at temperatures ranging from 25 to $35{ }^{\circ} \mathrm{C}$ (Martin and Loper, 1999). On turfgrass, $P$. aphanidermatum is more destructive when temperatures are between 29 and $35{ }^{\circ} \mathrm{C}$ (Abad et al., 1994; Vargas and Vargas, 1994). Several studies during the 70 s and 80s (Martin and Loper, 1999) indicated that severity of diseases caused by P. ultimum and $P$. irregulare increased at cool temperatures from 12 to $25^{\circ} \mathrm{C}$ in various hosts.

Our results indicate that the level of susceptibility to root rot for the geranium and snapdragon cultivars screened varies depending on the Pythium sp. No cultivar was completely resistant to root rot caused by $P$. aphanidermatum or $P$. irregulare. These results are consistent with an earlier study that evaluated 30 geranium cultivars for resistance to P. ultimum (Hausbeck et al., 1987). In our study, 'Ivy Summer Shower Fuchsia', 'Inspire Appleblosson Hybrid', and 'Ivy Tornado Red' were the least susceptible cultivars to $P$. aphanidermatum. The cultivars Nano White Hybrid, Bulls Eye Cherry, Horizon Red, and Ringo 2000 Red Deep had the lowest AUDPC and disease severity at 35 dpi when inoculated with $P$. irregulare. Hausbeck et al. (1987) showed that the cultivars Ringo Scarlet and Ringo Salmon, still available in the market, had a low percentage $(10 \%)$ of plant death in soilless media infested with $P$. ultimum.
Snapdragon cultivars Twinny White, Candy Shower Yellow, Montego White, and Arrow White were the least susceptible to $P$. aphanidermatum and $P$. irregulare in this study.

Sufficiently resistant geranium and snapdragon cultivars for effective disease management were not identified in our study. However, growers can integrate the fungicides mefenoxam, fenamidone, and azoxystrobin with biocontrol agents containing $S$. lydicus and T. harzianum, and with cultivars that are less susceptible to Pythium root rot, in an overall program to limit disease. Specifically, mefenoxam and $S$. lydicus were the best products for protecting geranium against $P$. aphanidermatum, $P$. irregulare, and $P$. ultimum. Fenamidone and mefenoxam were the best treatments against $P$. aphanidermatum and $P$. ultimum in snapdragon. The treatments etridiazole and fluopicolide were also effective at controlling $P$. ultimum, whereas $T$. harzianum, fenamidone and potassium phosphite were the best treatment to control $P$. irregulare infecting snapdragon. The development of fast and accurate diagnostic tools to identify Pythium sp. infecting floriculture crops is needed, to better tailor management strategies to effectively limit disease.

\section{Literature Cited}

Abad, Z., H. Shew, and L. Lucas. 1994. Characterization and pathogenicity of Pythium species isolated from turfgrass with symptoms of root and crown rot in North Carolina. Phytopathology 84:913-921.

Benson, D.M. and K.C. Parker. 2011. Efficacy of fungicides and biopesticides for management of Phytophthora crown and root rot of Gerber daisy. Online. Plant Health Progress, doi: 10.1094/ PHP-2011-0512-01-RS.

Chase, A.R. 1993. Review of fungicides for control of Phytophthora and Pythium diseases on potted ornamentals. Univ. Florida, IFAS, Central Florida Research and Education Center, Apopka.

Cohen, Y. and M.D. Coffey. 1986. Systemic fungicides and the control of oomycetes. Annu. Rev. Phytopathol. 24:311-338.

Cornell, U. 2012. 2012 Cornell guide for the integrated management of greenhouse floral crops. Cornell Univ., Riverhead, NY.

Daughtrey, M.L. and D.M. Benson. 2005. Principles of plant health management for ornamental plants. Annu. Rev. Phytopathol. 43:141-169.

Del Castillo-Múnera, J. and M. Hausbeck. 2014. Pythium spp. associated with greenhouse floriculture crops in Michigan. 2014 APS Annual Meeting, Minneapolis, MN.

Garzón, C.D., J.E. Molineros, J.M. Yánez, F.J. Flores, M. Del Mar Jiménez-Gasco, and G.W. Moorman. 2011. Sublethal doses of mefenoxam enhance Pythium damping-off of geranium. Plant Dis. 95:1233-1238.

Guetsky, R., D. Shtienberg, Y. Elad, E. Fischer, and A. Dinoor. 2002. Improving biological control by combining biocontrol agents each with several mechanisms of disease suppression. Phytopathology 92:976-985.

Gutiérrez, W., T. Melton, and A. Mila. 2012. Pythium root rot in flue-cured tobacco seedlings produced in greenhouses: Factors associated with its occurrence and chemical control. Online. Plant Health Progress, doi: 10.1094/PHP-2012-0925-01-RS.

Handelsman, J. and E.V. Stabb. 1996. Biocontrol of soilborne plant pathogens. Plant Cell 8:18551869. 
Harman, G.E. 2000. Myths and dogmas of biocontrol changes in perceptions derived from research on Trichoderma harzinum T-22. Plant Dis. 84:377-393.

Hausbeck, M. and B. Harlan. 2013. Pythium root rot in the greenhouse [Online]. East Lansing. Dec. 2013. <http://msue.anr.msu.edu/news/ pythium_root_rot_in_the_greenhouse $>$.

Hausbeck, M.K., C.T. Stephens, and R.D. Heins. 1987. Variation in resistance of geranium to Pythium ultimum in the presence or absence of silver thiosulphate. HortScience 22:940-944.

Kucharek, T. and D. Mitchell. 2000. Diseases of agronomic and vegetable crops caused by Pythium. Plant pathology fact sheet PP53. Institute of Food and Agriculture Service, Gainesville, FL.

Leisso, R., P. Miller, and M. Burrows. 2009. The influence of biological and fungicidal seed treatments on chickpea (Cicer arietinum) damping off. Can. J. Plant Pathol. 31:38-46.

Linderman, R.G., E.A. Davis, and C.J. Masters. 2008. Efficacy of chemical and biological agents to suppress Fusarium and Pythium damping-off of container-grown Douglas-fir seedlings. Plant Health Progr. 10.

Little, M., W. Brown, T. Blom, J. Gracia-Garza, K. Schneider, W. Allen, and J. Potter. 2003. Efficacy of various biological control agents and biorationals against Pythium root rot in poinsettia. HortTechnology 13:149-153.

Lu, X.H., R. Michael Davis, S. Livingston, J. Nunez, and J.J. Hao. 2012. Fungicide sensitivity of Pythium spp. associated with cavity spot of carrot in California and Michigan. Plant Dis. 96:384-388.

Martin, F.N. and J.E. Loper. 1999. Soilborne plant diseases caused by Pythium spp.: Ecology, epidemiology, and prospects for biological control. Crit. Rev. Plant Sci. 18:111-181.
Moorman, G., S. Kang, D. Geiser, and S. Kim. 2002. Identification and characterization of Pythium species associated with greenhouse floral crops in Pennsylvania. Plant Dis. $86: 1227-1231$.

Moorman, G. and S. Kim. 2004. Species of Pythium from greenhouses in Pennsylvania exhibit resistance to propamocarb and mefenoxam. Plant Dis. 88:630-632.

Olson, H. and D. Benson. 2011. Characterization of Phytophthora spp. on floriculture crops in North Carolina. Plant Dis. 95:1013-1020.

Parke, J.L. and N.J. Grünwald. 2012. A systems approach for management of pests and pathogens of nursery crops. Plant Dis. 96:1236-1244.

Paulitz, T.C. and R.R. Bélanger. 2001. Biological control in greenhouse systems. Annu. Rev. Phytopathol. 39:103-133.

Quesada-Ocampo, L., D. Fulbright, and M. Hausbeck 2009. Susceptibility of Fraser fir to Phytophthora capsici. Plant Dis. 93:135-141.

Robideau, G.P., A.W.A.M. De Cock, M.D. Coffey, H. Voglmayr, H. Brouwer, K. Bala, D.W. Chitty, N. Désaulniers, Q.A. Eggertson, and C.M.M. Gachon. 2011. DNA barcoding of oomycetes with cytochrome c oxidase subunit I and internal transcribed spacer. Mol. Ecol. Resour. 11:1002-1011.

Shaner, G. and R. Finney. 1977. The effect of nitrogen fertilization on the expression of slowmildewing resistance in Knox wheat. Phytopathology 67:1051-1056.

Stephens, C. and C. Powell. 1982. Pythium species causing damping-off of seedling bedding plants in Ohio greenhouses. Plant Dis. 66:731-733.

Stiles, C.M., L.E. Datnoff, and J.L. Cisar. 2005. Evaluation of fungicides for control of Pythium blight in overseeded turfgrasses using a simple field inoculation technique. Plant Health Progress 10.
Taylor, R., B. Salas, G. Secor, V. Rivera, and N. Gudmestad. 2002. Sensitivity of North American isolates of Phytophthora erythroseptica and Pythium ultimum to mefenoxam (metalaxyl). Plant Dis. 86:797-802.

USDA. 2013. Floriculture crops 2012 Summary [Online]. Dec. 2013. <http://usda01.library. cornell.edu/usda/current/FlorCrop/FlorCrop-0425-2013.pdf>.

USDA. 2014. Floriculture crops 2013 Summary [Online]. Jan. 2015. <http://usda.mannlib. cornell.edu/usda/current/FlorCrop/FlorCrop06-19-2014.pdf>.

van Der Plaats-Niterink, A.J. 1981. Monograph of the genus Pythium, Centraalbureau voor Schimmelcultures Baarn.

Vargas, J.M., Jr., and J. Vargas. 1994. Management of turfgrass diseases. CRC Press.

Weiland, J.E. 2011. Influence of isolation method on recovery of Pythium species from forest nursery soils in Oregon and Washington. Plant Dis. 95:547-553.

Weiland, J.E. 2014. Pythium species and isolate diversity influence inhibition by the biological control agent Streptomyces lydicus. Plant Dis. 98:653-659.

Whipps, J.M. and M.P. Mcquilken. 2009. Biological control agents in plant disease control. Disease control in crops: biological and Environmentally friendly approaches. Wiley-Blackwell, Oxford, UK.

White, T.J., T. Bruns, S. Lee, and J. Taylor. 1990. Amplification and direct sequencing of fungal ribosomal RNA genes for phylogenetics. PCR protocols: A guide to methods and applications. 18:315-322.

Yuan, W.M. and D.L. Crawford. 1995. Characterization of Streptomyces lydicus WYEC108 as a potential biocontrol agent against fungal root and seed rots. Appl. Environ. Microbiol. 61:3119-3128. 